\title{
NILAI TAMBAH KEDELAI MENJADI TAHU KUNING DAN FAKTOR-FAKTOR YANG MEMENGARUHINYA
}

\author{
Dinda Yunita Yosifani*, Ratna Satriani, Dindy Darmawati Putri \\ Program Studi Agribisnis, Fakultas Pertanian, Universitas Jenderal Soedirman \\ Jl. Dr. Soeparno No.6, Karang Bawang, Grendeng Purwokerto 53122 \\ *Corresponding author: dindayunita62@gmail.com
}

\begin{abstract}
One of the home industries for processing soybeans into tofu is located in Kalisari Village, which has been producing since 1965. This business serves as a diversification of the business that can increase household income. This study aims to 1) determine the added value of soybeans obtained by producers, 2) determine the distribution of the added value of soybeans to yellow tofu, and 3) determine the factors that affect the added value of soybean on yellow tofu production. The research was conducted on tofu producer in the Sari Delai Group in Kalisari Village, Cilongok Subdistrict, Banyumas Regency in June-July 2020. Then added value analysis is carried out by using the method of Hayami and multiple linear regression. The results showed that $1 \mathrm{~kg}$ of soybean raw material used for yellow tofu will provide an added value of Rp11,628.00. The distribution of added value for labor income was 13.38 percent, other input contributions by 18.54 percent and for profit 68\%. The production capacity, raw materials, labor, output price and other input contributions have significant effect on the added value of yellow tofu production. In contrast, labor wage and raw material prices have no effect on the added value of yellow tofu production.
\end{abstract}

Keywords: home industries, yellow tofu, soybean, added value

\begin{abstract}
Abstrak: Salah satu industri rumah tangga pengolahan kedelai menjadi tahu terdapat di Desa Kalisari yang telah berproduksi sejak tahun 1965. Usaha ini berfungsi sebagai salah satu diversifikasi usaha yang dapat meningkatkan penghasilan keluarga. Penelitian ini bertujuan untuk 1) mengetahui besarnya nilai tambah kedelai yang diperoleh produsen, 2) Mengetahui distribusi nilai tambah kedelai menjadi tahu kuning, dan 3) Mengetahui faktor-faktor yang memengaruhi nilai tambah produksi kedelai menjadi tahu kuning. Penelitian dilakukan pada pengrajin tahu Kelompok Sari Delai di Desa Kalisari Kecamatan Cilongok Kabupaten Banyumas yang dilakukan pada bulan Juni-Juli 2020. Kemudian dilakukan analisis nilai tambah menggunakan metode Hayami dan regresi linier berganda. Hasil penelitian menunjukan bahwa dari 1 $\mathrm{kg}$ bahan baku kedelai yang digunakan untuk tahu kuning akan memberikan nilai tambah sebesar Rp11.628,00. Distribusi nilai tambah untuk pendapatan tenaga kerja sebesar 13,38\%, sumbangan input lain sebesar 18,54\% dan untuk keuntungan sebesar $68 \%$. Faktor-faktor yang berpengaruh signifikan terhadap nilai tambah pada produksi tahu kuning adalah kapasitas produksi, bahan baku, tenaga kerja, harga output dan sumbangan input lain. Sedangkan upah tenaga kerja dan harga bahan baku tidak berpengaruh terhadap nilai tambah pada produksi tahu kuning.
\end{abstract}

Kata kunci: industri rumah tangga, tahu kuning, kedelai, nilai tambah

\section{PENDAHULUAN}

Indonesia adalah salah satu negara yang memiliki sumber daya alam berupa lahan yang relatif cukup luas dan subur dengan iklim, suhu dan kelembaban yang cocok untuk kebutuhan pertumbuhan tanaman pangan pokok, maka hampir seluruh tanaman pangan pokok tersebut 
(biji-bijian, umbi-umbian dan kacang-kacangan asli Indonesia) dapat tumbuh dengan relatif baik. Salah satu jenis tanaman pangan yang dibutuhkan oleh sebagian besar penduduk Indonesia adalah tanaman kedelai (Andarwulan, 2018).

Kedelai adalah salah satu tanaman polong-polongan yang menjadi sumber utama protein dan minyak nabati utama dunia. Kedelai merupakan tanaman pangan utama strategis terpenting setelah padi dan jagung. Begitu besarnya kontribusi kedelai dalam hal penyediaan bahan pangan bergizi bagi manusia sehingga kedelai biasa dijuluki sebagai Gold from the Soil atau sebagai World's Miracle mengingat kualitas asam amino proteinnya yang tinggi, seimbang dan lengkap (Abdillah, 2015).

Konsumsi kedelai oleh masyarakat Indonesia yang semakin tinggi seiring bertambahnya jumlah penduduk, peningkatan pendapatan perkapita dan kesadaran masyarakat akan gizi makanan membuat produksi kedelai dalam negeri tidak mampu memenuhi kebutuhan konsumsi masyakarakat Indonesia, sehingga, Indonesia perlu mendatangkan kedelai dari negara Jepang dan China karena kedelai putih bukan asli tanaman tropis sehingga hasilnya selalu lebih rendah dari negara Jepang dan China. Pemanfaatan utama kedelai adalah dari biji yang dapat dibuat menjadi tahu.

Perkembangan dunia usaha pada era globalisasi di Indonesia berkembang dengan pesat. Hal ini dibuktikan dengan munculnya berbagai macam usaha, mulai dari usaha kecil yang dimiliki perseorangan maupun perusahaan yang telah berkembang dan telah memiliki cabang diberbagai daerah. Industri kreatif dengan skala kecil menengah atau yang lebih dikenal dengan istilah Usaha Mikro Kecil Menengah (UMKM) merupakan salah satu sektor yang menyokong perekonomian Indonesia.

Agroindustri pengolahan kedelai menjadi tahu merupakan proses transformasi melalui perubahan fisik atau kimiawi, penyimpanan, pengepakan, dan distribusi. Agroindustri pengolahan hasil pertanian, mempunyai ciri-ciri sebagai berikut: (a) dapat meningkatkan nilai tambah, (b) menghasilkan produk yang dapat dipasarkan atau digunakan atau dimakan, (c) meningkatkan daya saing, dan (d) menambah penghasilan dan keuntungan bagi produsen.

Nilai tambah merupakan perbedaan nilai suatu produk sebelum dilakukan proses produksi dengan setelah dilakukan proses produksi sehingga menghasilkan produk yang dapat dipasarkan dan akan memberikan pendapatan bagi agroindustri itu sendiri serta meningkatkan perekonomian masyarakat sekitar daerah tersebut. Selain itu, dengan adanya proses produksi akan menciptakan kesempatan kerja dan mampu mengurangi jumlah pengguran di Indonesia.

Analisis nilai tambah metode Hayami adalah suatu metode yang digunakan untuk mengetahui sejauh mana bahan baku yang mendapatkan perlakuan mengalami perubahan nilai. Metode ini bermanfaat untuk mengetahui kondisi perolehan kekayaan perusahaan sebagai hasil dari proses produksi dan juga menunjukkan distribusi nilai tambah yang dihasilkan terhadap faktor produksi yang digunakan. Menurut Hayami et.al (1987) dalam (Sudiyono, 2004), ada dua cara untuk menghitung nilai tambah yaitu nilai tambah untuk pengolahan dan nilai tambah untuk pemasaran. Faktor-faktor yang memengaruhi nilai tambah untuk pengolahan dapat dikategorikan menjadi dua yaitu faktor teknis dan faktor pasar. Faktor teknis yang berpengaruh adalah kapasitas produksi, jumlah bahan baku yang digunakan dan tenaga kerja. Sedangkan faktor pasar yang berpengaruh adalah harga output, upah tenaga kerja, harga bahan baku dan nilai input lain, selain bahan bakar dan tenaga kerja.

Salah satu cara yang dapat dilakukan agar nilai tambah suatu komoditas pertanian meningkat adalah dengan mengaitkan pertanian dengan industri pengolahan. Jika pertanian hanya berhenti sebagai aktivitas budidaya (onfarm agribusiness), maka nilai tambah yang dihasilkan akan relatif kecil. Akan tetapi, nilai tambah pertanian akan meningkat jika melalui proses pengolahan lebih lanjut atau kegiatan sampai kepada sektor hilir (off-farm agribussiness) yang menghasilkan bermacammacam produk olahan.

Industri kecil yang ada di Indonesia mayoritas memproduksi makanan dan kerajinan tangan. Salah satunya seperti yang ada di Kabupaten Banyumas terdapat banyak industri kecil yang memproduksi makanan 
seperti gethuk, tempe, tahu dan sebagainya. Agroindustri di wilayah Banyumas juga berkaitan dengan pembangunan di sektor industri kreatif, dengan pemberdayaan masyarakat melalui usaha mikro dan kecil. Secara umum, pengembangan agroindustri di Kabupaten Banyumas memberikan kontribusi penting bagi peningkatan nilai tambah dari sektor pertanian menjadi industri pengolahan. Beberapa agroindustri di Kabupaten Banyumas telah memanfaatkan sumber daya lokal berupa kedelai. Produk pengolahan kedelai juga dapat dijadikan sebagai bahan baku agroindustri lain, sehingga muncul suatu rantai produksi dengan basis komoditas kedelai seperti di Desa Kalisari Kecamatan Cilongok yang sudah dijadikan sebagai sentra tahu.

Industri pengolahan kedelai yang ada di Desa Kalisari berbentuk industri rumah tangga, sehingga hampir setiap rumah memproduksi tahu. Industri ini sudah ada sejak tahun 1965 hingga sekarang, usaha ini berfungsi sebagai salah satu diversifikasi usaha yang dapat meningkatkan penghasilan keluarga dan mencukupi kebutuhan, menampung banyak tenaga kerja, sehingga dapat mengurangi tingkat pengangguran. Masyarakat Desa Kalisari khususnya pengusaha kedelai terus berusaha menjalankan industri dengan harapan usaha ini dapat mencukupi kebutuhan seharihari, dan agroindustri kedelai mempunyai potensi untuk dikembangkan. Usaha ini kebanyakan dijalankan secara turun temurun dan dijadikan sebagai sumber pemasukan utama mayoritas masyarakat Desa Kalisari. Maka dari itu penelitian ini bertujuan untuk mengetahui besarnya nilai tambah kedelai yang diperoleh produsen, distribusi nilai tambah kedelai menjadi tahu kuning, dan faktor-faktor yang memengaruhi nilai tambah produksi kedelai menjadi tahu kuning.

\section{METODE PENELITIAN}

Penelitian ini dilakukan pada kelompok usaha tahu kuning "Sari Delai" yang berlokasi di Desa Kalisari Kecamatan Cilongok Kabupaten Banyumas. Penelitian ini dilaksanakan pada bulan Juni hingga Juli 2020. Obyek penelitian ini adalah pengrajin tahu kuning pada Kelompok Sari Delai Desa kalisari Kecamatan Cilongok Kabupaten Banyumas yang melakukan produksi dalam satu hari. Metode yang digunakan pada penelitian ini adalah studi kasus pada kelompok pengrajin tahu "Sari Delai" Desa Kalisari. Studi kasus adalah suatu metode untuk mendapatkan keterangan yang jelas dan baik secara menyeluruh dan mendalam dari masalah yang diteliti dalam suatu usaha tertentu dan suatu kasus dalam suatu usaha merupakan hal khusus, berbeda dari yang lain dan tidak dapat digeneralisasikan (Nazir, 2011).

\section{Rancangan Penentuan Responden}

Metode pengambilan sampel yang digunakan pada penelitian ini adalah metode probability sampling yaitu teknik pengambilan sampel yang memberikan peluang atau kesempatan yang sama bagi setiap unsur atau anggota populasi untuk dipilih menjadi sampel (Sugiyono, 2017). Metode probability sampling yang digunakan adalah teknik random sampling (sampel acak). Random sampling adalah teknik pengambilan sampel dimana semua individu dalam populasi baik secara sendiri-sendiri atau bersama-sama diberi kesempatan yang sama untuk dipilih sebagai anggota sampel. Berdasarkan perhitungan koefisien varian yang dihasilkan sebesar $8,13 \%$. Hal tersebut menunjukkan bahwa populasi pengrajin tahu pada Kelompok Sari Delai Desa Kalisari Kabupaten Banyumas bersifat homogen karena memiliki koefisien varian kurang dari $30 \%$.

Jumlah populasi dalam penelitian ini dapat ditentukan. Menurut (Sugiyono, 2017), sampel adalah bagian dari jumlah dan karakteristik yang dimiliki oleh populasi. Untuk menentukan besarnya sampel yang akan diambil dari populasi maka peneliti menggunakan rumus yang dikemukakan oleh Slovin dengan tingkat kepercayaan 90\% dengan nilai $\mathrm{e}=10 \%$ adalah sebagai berikut:

$$
n=\frac{N}{1+N e^{2}}
$$

Keterangan :

$\mathrm{n}=$ Jumlah sampel

$\mathrm{N}=$ Jumlah populasi

$\mathrm{e}=$ Tingkat kesalahan dalam memilih anggota sampel yang ditolelir sebesar $10 \%$ 
Sampel yang masih dapat ditolelir atau diinginkan sebanyak $10 \%$, yaitu:

$$
\begin{aligned}
\mathrm{n} & =\frac{68}{1+68(0,1)^{2}} \\
& =40,4 \text { atau } 40 \text { sampel }
\end{aligned}
$$

Maka dapat disimpulkan bahwa sampel pada penelitian ini menggunakan 40 pengrajin tahu Sari Delai.

\section{Analisis Data}

Nilai tambah adalah selisih antara biaya output dan nilai input. Variabel nilai tambah terdiri dari hasil produksi (output), bahan baku (input), tenaga kerja, harga bahan baku, harga produk, upah tenaga kerja, serta jumlah input lain yang digunakan. Analisis nilai tambah menggunakan metode Hayami, menghasilkan nilai tambah yang diterima pada setiap elemennya. Kelebihan metode ini pada kemudahan pemahaman dan penggunaannya serta memberikan informasi cukup lengkap untuk pelaku maupun investor serta pekerja (Priantara, 2016).

Hayami (1987) dalam (Sudiyono, 2004) menyatakan bahwa perhitungan nilai tambah dibagi menjadi dua macam metode yaitu metode perhitungan nilai tambah untuk kegiatan pengolahan dan untuk kegiatan pemasaran (Tabel 1). Dari hasil perhitungan tersebut, akan dihasilkan keterangan sebagai berikut:

\begin{tabular}{|c|c|c|}
\hline No & Variabel & Nilai \\
\hline \multirow[t]{8}{*}{ I } & Output, Input dan Harga & \\
\hline & 1. Output (Kg/hari) & A \\
\hline & 2. Input (Kg/hari) & B \\
\hline & 3. Tenaga kerja (HOK/hari) & $\mathrm{C}$ \\
\hline & 4. Faktor konversi (Kg output/ Kg bahan baku) & $\mathrm{D}=\mathrm{A} / \mathrm{B}$ \\
\hline & 5. Koefisien tenaga kerja (HOK/Kg bahan baku) & $\mathrm{E}=\mathrm{C} / \mathrm{B}$ \\
\hline & 6. Harga Output $(\mathrm{Rp} / \mathrm{Kg})$ & $\mathrm{F}$ \\
\hline & 7. Upah rata-rata tenaga kerja $(\mathrm{Rp} / \mathrm{Kg})$ & G \\
\hline \multirow[t]{10}{*}{ II } & Pendapatan dan Nilai Tambah (Rp/Kg) & \\
\hline & 8. Harga bahan baku (Rp/Kg) & $\mathrm{H}$ \\
\hline & 9. Sumbangan input lain (Rp/Kg output) & I \\
\hline & 10. Nilai Output $(\mathrm{Rp} / \mathrm{Kg})$ & $\mathrm{J}=\mathrm{D} \times \mathrm{F}$ \\
\hline & 11. a. Nilai tambah (RP/kg) & $\mathrm{K}=\mathrm{J}-\mathrm{H}-\mathrm{I}$ \\
\hline & b. Rasio nilai tambah (\%) & $\mathrm{L} \%=(\mathrm{K} / \mathrm{J}) \times 100 \%$ \\
\hline & 12. a. Pendapatan tenaga kerja $(\mathrm{Rp} / \mathrm{Kg})$ & $\mathrm{M}=\mathrm{E} \times \mathrm{G}$ \\
\hline & b. Bagian tenaga kerja (\%) & $\mathrm{N} \%=(\mathrm{M} / \mathrm{K}) \times 100 \%$ \\
\hline & 13. a. Keuntungan $(\mathrm{Rp} / \mathrm{Kg})$ & $\mathrm{O}=\mathrm{K}-\mathrm{M}$ \\
\hline & b. Bagian keuntungan (\%) & $\mathrm{P} \%=(\mathrm{O} / \mathrm{K}) \times 100 \%$ \\
\hline \multirow[t]{5}{*}{ III } & Balas Jasa Faktor Produksi & \\
\hline & 14. Marjin (Rp/Kg) & $\mathrm{Q}=\mathrm{J}-\mathrm{H}$ \\
\hline & a. Sumbangan input lain (\%) & $\mathrm{R} \%=(\mathrm{I} / \mathrm{Q}) \times 100 \%$ \\
\hline & b. Pendapatan tenaga kerja (\%) & $\mathrm{S} \%=(\mathrm{M} / \mathrm{Q}) \times 100 \%$ \\
\hline & c. Keuntungan $(\%)$ & $\mathrm{T} \%=(\mathrm{O} / \mathrm{Q}) \times 100 \%$ \\
\hline
\end{tabular}

Tabel 1. Format Analisis Nilai Tambah

Sumber : Hayami et.al (1987) dalam (Sudiyono, 2004) 
1. Perkiraan nilai tambah (dalam rupiah)

2. Rasio nilai tambah terhadap nilai produk yang dihasilkan (dalam \%)

3. Imbalan bagi tenaga kerja (dalam rupiah)

4. Imbalan bagi modal dan manajemen (keuntungan yang diterima perusahaan, dalam rupiah)

Distribusi nilai tambah berhubungan dengan teknologi yang diterapkan dalam proses pengolahan, kualitas tenaga kerja berupa keahlian dan keterampilan serta kualitas bahan baku. Penerapan teknologi yang cenderung padat karya akan memberikan proporsi bagian terhadap tenaga kerja yang besar daripada proporsi bagian keuntungan dari perusahaan, sedangkan bila yang diterapkan teknologi padat modal maka besarnya proporsi bagian pengusaha lebih besar daripada proporsi bagian tenaga kerja.

Analisis regresi linear berganda menurut (Gujarati, 2006) yaitu suatu alat analisis yang bertujuan untuk menguji pengaruh antara satu variabel terhadap variabel lain. Variabel yang dipengaruhi disebut variabel dependent, sedangkan variabel yang memengaruhi disebut variabel bebas atau variabel independent. Analisis regresi berganda merupakan alat analisis peramalan nilai dua atau lebih variabel bebas $(\mathrm{X})$ terhadap satu variabel terikat $(\mathrm{Y})$.

Rancangan model yang akan diajukan adalah model regresi linier berganda dengan tujuh variabel bebas. Variabel independentnya adalah kapasitas produksi, jumlah bahan baku, tenaga kerja, harga output, upah tenaga kerja, harga bahan baku dan sumbangan input lain.Berdasarkan data yang tersedia persamaan regresi yang digunakan adalah sebagai berikut:

$$
\begin{aligned}
\mathrm{Y}= & \alpha+\beta_{1} \mathrm{X} 1+\beta_{2} \mathrm{X} 2+\beta_{3} \mathrm{X} 3+\beta_{4} \mathrm{X} 4+\beta_{5} \mathrm{X} 5+ \\
& \beta_{6} \mathrm{X} 6+\beta_{7} \mathrm{X} 7+\mathrm{e}
\end{aligned}
$$

$$
\begin{aligned}
& \text { Keterangan: } \\
& \mathrm{Y}=\text { Nilai Tambah }(\mathrm{Rp} / \mathrm{kg}) \\
& \mathrm{X} 1=\text { Kapasitas Produksi }(\mathrm{kg}) \\
& \mathrm{X} 2=\text { Jumlah Bahan Baku }(\mathrm{kg}) \\
& \mathrm{X} 3=\text { Tenaga Kerja }(\mathrm{HOK}) \\
& \mathrm{X} 4=\text { Harga Output }(\mathrm{Rp}) \\
& \mathrm{X} 5=\text { Upah Tenaga Kerja }(\mathrm{Rp}) \\
& \mathrm{X} 6=\text { Harga Bahan Baku }(\mathrm{Rp}) \\
& \mathrm{X} 7=\text { Sumbangan Input Lain }(\mathrm{Rp}) \\
& \mathrm{e} \quad=\text { error }
\end{aligned}
$$

Koefisien determinasi $\left(\mathrm{R}^{2}\right)$ adalah mengukur seberapa jauh kemampuan model dalam menerangkan variasi variabel dependen. Nilai koefisien determinasi adalah antara nol dan satu. Nilai $R^{2}$ yang kecil berarti kemampuan variabel-variabel independen dalam menjelaskan variasi variabel-variabel dependen sangat terbatas.

Uji $F$ digunakan untuk mengetahui pengaruh kapasitas produksi, jumlah bahan baku, tenaga kerja, harga output, upah tenagaa kerja dan harga bahan baku secara bersamasama terhadap nilai tambah kedelai pada produksi tahu. Uji $t$ digunakan untuk mengetahui pengaruh kapasitas produksi, jumlah bahan baku, tenaga kerja, harga output, upah tenagaa kerja dan harga bahan baku secara parsial terhadap nilai tambah produk tahu di desa Kalisari Kecamatan Cilongok.

\section{HASIL DAN PEMBAHASAN}

\section{Identifikasi Pengrajin Tahu Desa Kalisari}

Desa Kalisari merupakan salah satu desa di Kecamatan Cilongok yang memiliki industri rumah tangga pembuatan tahu yang ada di Desa Kalisari sebanyak 226 industri dengan tenaga kerja sebanyak 652 orang sehingga Desa Kalisari dikenal sebagai sentra industri tahu di Kabupaten Banyumas. Pengrajin tahu yang ada tergabung dalam kelompok pengrajin yaitu Sari Delai. Kelompok pengrajin ini berdiri pada tahun 2014 yang diprakarsai oleh Kepala Desa Kalisari dan beranggotakan 68 orang.

Kelompok pengrajin Sari Delai telah mempunyai hak paten atas nama "Tahu Sari Delai" dengan nomor REG.DIY2014.00350. Setiap anggota kelompok berhak untuk mencantumkan nomor tersebut dan mencantumkan nomor PIRT yang telah dimiliki. Tujuannya adalah untuk menguatkan proses pemasaran, selain itu juga untuk menghindari kerugian dengan adanya pengrajin tahu yang bukan berasal dari Desa Kalisari yang menggunakan label produk tahu Kalisari.

Tujuan dibentuknya kelompok untuk memudahkan koordinasi antar pengrajin mengenai proses produksi hingga pemasarannya dengan diadakannya pertemuan rutin. Pertemuan tersebut diadakan sekali dalam satu bulan secara bergiliran pada rumah tiap anggota. Setiap anggota diwajibkan untuk iuran sebesar Rp50.000,00 tiap bulannya untuk 
kas kelompok yang nantinya dapat digunakan oleh anggota untuk dipinjam sebagai tambahan modal atau untuk keperluan sehari-hari. Selain itu, anggota juga wajib membeli salah satu bahan-bahan produksi yang telah disediakan oleh kelompok, seperti garam, kunyit, plastik, dan solar, kewajiban tersebut bertujuan untuk dapat menghidupkan kelompok dengan membantu sesama anggota. Harga yang diberikan oleh kelompok Sari Delai sama dengan harga di toko yang lain dan dapat diantar tiap hari ke rumah masing-masing anggota. Keuntungan lain yang didapat oleh anggota kelompok adalah adanya penyuluhanpenyuluhan mengenai pengolahan tahu hingga pemasarannya yang diadakan oleh badan-badan terkait, mudahnya akses untuk mendapatkan bantuan dana, dan dapat mengatasi permasalahan yang dihadapi tiap anggota.

Responden dalam penelitian ini adalah kelompok pengrajin tahu Sari Delai yang memproduksi tahu kuning sebanyak 40 orang. Karakteristik responden yang diamati meliputi usia, pendidikan terakhir, pekerjaan sampingan, jumlah tanggungan keluarga, dan lama usaha.

1. Usia responden

Usia responden berhubungan dengan produktivitas maupun motivasinya dalam bekerja. Kelompok Sari Delai berada pada usia produktif yaitu usia 15 sampai 64 tahun, dengan rata-rata usia 50,35 tahun. Hal ini menunjukan secara fisik anggota kelompok masih memiliki potensi yang besar menghasilkan pendapatan untuk mencukupi kebutuhan sehari-hari dari usaha tahu.

\section{Pendidikan terakhir}

Pendidikan juga memberikan pengaruh terhadap berkembangnya usaha yang dimilikinya. Semakin tinggi pendidikan yang ditempuh maka semakin baik pula dalam proses manajemen usahanya. Kelompok Sari Delai mempunyai tingkat pendidikan terakhir tertinggi pada jenjang SD yaitu sebanyak 30 orang $(75 \%)$. Hal ini menunjukkan bahwa sebagian besar anggota kelompok Sari Delai memiliki tingkat pendidikan masih rendah. Tingkat pendidikan ini akan berpengaruh pada cara pengelolaan atau manajemen usaha tahu yang dimiliki masing-masing anggota. Pendidikan non formal seperti pelatihan maupun penyuluhan dari badan-badan terkait sangat dibutuhkan untuk memperbaiki manajemen usaha, nantinya akan berpengaruh pada kesejahteraan masing-masing anggota.

3. Jumlah anggota keluarga

Jumlah anggota keluarga adalah jumlah anggota keluarga dari suatu rumah tangga. Sebesar 75 persen anggota kelompok Sari Delai memiliki anggota keluarga 2-4 orang. Jumlah anggota keluarga akan berpengaruh pada banyaknya penggunaan tenaga kerja. Penggunaan tenaga kerja dalam keluarga akan mengurangi pengeluaran untuk upah tenaga kerja, sehingga dapat meningkatkan keuntungan.

4. Pekerjaan sampingan

Anggota kelompok Sari Delai yang tidak mempunyai pekerjaan sampingan sebesar $60 \%$. Hal ini menunjukan bahwa sebagian besar anggota kelompok bertumpu pada usaha tahu untuk mencukupi kebutuhan sehari-hari.

5. Lama usaha

Salah satu faktor yang memengaruhi tingkat pendapatan adalah lama usaha. Rata-rata pengrajin tahu di Desa Kalisari sudah mengajalankan usaha tersebut selama 22-27 tahun. Hal ini menunjukan bahwa anggota kelompok pengrajin tahu Sari Delai dapat meningkatkan pendapatannya melalui pengalaman berusaha yang telah dijalani. Lama usaha menunjukkan eksistensi usaha tersebut bertahan dan sebagai indikator untuk mengukur besar pengalaman yang dimiliki oleh pedagang. Semakin lama sebuah usaha, maka pengalaman yang dimiliki oleh pedagang akan semakin banyak.

\section{Analisis Nilai Tambah}

Analisis nilai tambah digunakan untuk mengetahui besarnya nilai tambah yang diperoleh dari pengolahan kedelai menjadi tahu kuning. Hasil analisis nilai tambah tahu kuning pada Kelompok Sari Delai di Desa Kalisari dapat dilihat pada Tabel 2.

Hasil perhitungan nilai tambah pada Tabel 2 dapat dijelaskan bahwa rata-rata hasil produksi (output) tahu kuning di Desa Kalisari dalam satu hari produksi sebesar 78,97 $\mathrm{kg}$. Rata-rata penggunaan bahan baku (input) kedelai dalam satu hari sebesar 41,33 kg dengan rata-rata penggunaan tenaga kerja sebesar 2,240 HOK.

Nilai faktor konversi merupakan hasil bagi antara hasil produksi dan bahan baku, berdasarkan perhitungan diatas diperoleh nilai 
faktor konversi sebesar 1,91 yang artinya satu kilogram bahan baku dapat menghasilkan 1,91 kilogram tahu kuning.

Pada penelitian yang dilakukan oleh Setyawan et al. (2016) dengan judul "Permintaan kedelai pada industri rumah tangga tahu di Kabupaten Sleman" bahwa nilai faktor konversi 2,093 menunjukkan bahwa setiap $1 \mathrm{~kg}$ bahan baku kedelai dapat menghasilkan 2,093 $\mathrm{kg}$ produk tahu kuning. Nilai koefisien tenaga kerja diperoleh dari nilai tenaga kerja (HOK) dibagi dengan nilai bahan baku (kg) yang artinya menggambarkan penggunaan tenaga kerja pada pengolahan kedelai menjadi tahu kuning. Koefisien tenaga kerja yang dibutuhkan untuk mengolah satu kilogram kedelai menjadi tahu kuning sebanyak
0,054 HOK. Jenis kedelai IP New memiliki rendemen tertinggi dibandingkan dengan jenis yang lain yaitu sebesar $195.60 \%$, sedangkan jenis Indonesia memiliki nilai rendemen yang paling rendah yaitu sebesar $169.00 \%$. Nilai rendemen ini menunjukan banyaknya tahu yang dihasilkan dari jumlah kedelai yang sama pada setiap jenis kedelai yang digunakan dalam pembuatan tahu (Andarwulan, 2018).

Nilai output menunjukkan jumlah penerimaan kotor yang dihasilkan dari pengolahan setiap satu kilogram bahan baku kedelai. Rata-rata nilai output diperoleh dari hasil kali antara faktor konversi bahan baku dengan harga output. Nilai output tahu kuning sebesar Rp21.593,00 per kilogram. Nilai tersebut dialokasikan untuk bahan baku utama

Tabel 2. Nilai tambah tahu kuning di Desa Kalisari dalam satu hari produksi

\begin{tabular}{rrr}
\hline No & Variabel & Nilai \\
\hline I & Output, Input dan Harga & \\
\hline & 1. Output (kg/hari) & 78,97 \\
2. Input (kg/hari) & 41,32 \\
3. Tenaga kerja (HOK/hari) & 2,240 \\
4. Faktor konversi (kg output/kg bahan baku) & 1,91 \\
5. Koefisien tenaga kerja (HOK/kg bahan baku) & 0,054 \\
6. Harga Output (Rp/kg) & 11.299 \\
7. Upah rata-rata tenaga kerja (Rp/Hari) & 35.250 \\
\hline Pendapatan dan Nilai Tambah (Rp/kg) & \\
\hline 8. Harga bahan baku (Rp/kg) & $7.317,5$ \\
9. Sumbangan input lain (Rp/kg output) & $2.647,6$ \\
10. Nilai Output (Rp/kg) & $21.593,1$ \\
11. a. Nilai tambah (Rp/kg) & 11628 \\
b. Rasio nilai tambah (\%) & 53,85 \\
12. a. Pendapatan tenaga kerja (Rp/kg) & 1911 \\
b. Bagian tenaga kerja (\%) & 16,43 \\
13. a. Keuntungan (Rp/kg) & 9.717 \\
b. Bagian keuntungan (\%) & 83,5 \\
\hline Balas Jasa Faktor Produksi & \\
\hline 14. Marjin (Rp/kg) & $14.275,6$ \\
a. Sumbangan input lain (\%) & 18,54 \\
b. Pendapatan tenaga kerja (\%) & 13,38 \\
c. Keuntungan (\%) & 68,00 \\
\hline III &
\end{tabular}

Sumber: Data Primer Diolah, 2020. 
berupa kedelai dan sumbangan input lain masing-masing rata-rata sebesar Rp7.317,50 per kilogram dan Rp2.647,6 per kilogram bahan baku.

Nilai sumbangan input lain merupakan nilai semua korbanan selain bahan baku utama dan tenaga kerja langsung yang terjadi pada proses produksi berlangsung dengan membagi total sumbangan input lain dengan jumlah bahan baku. Sumbangan input lain tersebut terdiri dari biaya bahan bakar, biaya kemasan, biaya transportasi, biaya retribusi pasar, biaya penyusutan bangunan dan biaya penyusutan peralatan.

Nilai tambah yang dihasilkan dari pengolahan kedelai menjadi tahu kuning merupakan selisih antara nilai produk dengan harga bahan baku utama dan sumbangan input lain yaitu sebesar Rp11.628,00 dengan rasio nilai tambah sebesar 53,8\% terhadap nilai output. Rasio nilai tambah menunjukkan bahwa setiap Rp100,00 dari nilai output akan mendapatkan nilai tambah rata-rata $\mathrm{Rp} 53,8$. Nilai tersebut berasal dari setiap kilogram pengolahan kedelai menjadi tahu kuning. Hasil dari perhitungan nilai tambah, dapat diketahui kategori agroindustri bernilai tambah rendah, sedang dan tinggi. Kategori nilai tambah adalah sebagai berikut: 1) nilai tambah dikatakan rendah jika nilai rasio $<15 \%$, 2) Nilai tambah dikatakan sedang jika nilai rasio $15 \%-40 \%, 3$ ) Nilai tambah dikatakan tinggi jika nilai rasio $>40 \%$ (Ariyanti, 2019). Nilai tambah pengolahan tahu kuning di Desa Kalisari Rp11.628 atau 53,84\%. Rasio nilai tambah pengolahan kedelai menjadi tahu kuning termasuk dalam rasio tinggi. Rasio nilai tambah juga ditemukan pada penelitian Azmita (2019), dengan rasio nilai tambah pengolahan kedelai menjadi tahu sebesar $50,70 \%$, yang tergolong tinggi dikarenakan hasil yang didapatkan melebihi $40 \%$.

Nilai pendapatan tenaga kerja dari pengolahan kedelai menjadi tahu kuning sebesar Rp1.911 per kilogram menunjukkan jumlah pendapatan yang diterima tenaga kerja setiap kilogram kedelai. Bagian tenaga kerja sebesar $16,4 \%$ dari nilai tambah yang artinya, setiap $\mathrm{Rp} 100,00$ dari nilai tambah maka nilai bagian untuk tenaga kerja sebesar Rp16,4. Pendapatan tersebut diperoleh dari hasil perkalian antara koefisien tenaga kerja dengan upah rata-rata tenaga kerja.
Keuntungan yang diterima produsen tahu kuning di Desa Kalisari sebesar Rp9.717 per kilogram menunjukkan jumlah keuntungan bersih yang diterima produsen dari pengolahan setiap kilogram kedelai. Bagian keuntungan sebesar $83,5 \%$ dari nilai tambah, artinya setiap Rp100,00 dari nilai tambah akan mendapatkan keuntungan sebesar Rp83,5. Keuntungan tersebut berasal dari selisih nilai tambah dengan pendapatan tenaga kerja setiap kilogram kedelai.

Nilai marjin diperoleh dari selisih antara nilai output dengan harga bahan baku. Marjin menunjukkan kontribusi faktor-faktor produksi selain bahan baku utama dalam menghasilkan produk. Rata-rata balas jasa atau imbalan untuk pemilik faktor produksi yang dilihat dari besarnya marjin sebesar Rp14.275,60. Nilai tersebut didistribusikan untuk pendapatan tenaga kerja sebesar 13,3\%, sumbangan input lain sebesar $18,54 \%$ dan untuk keuntungan sebesar 68\%. Distribusi marjin terbesar untuk keuntungan produsen. Hal tersebut menunjukkan bahwa produksi tahu kuning dapat mencapai tingkat keuntungan yang tinggi. Menurut Hasanah, et al. (2015), apabila agroindustri yang ada tingkat keuntungan yang didapatkan (dalam persen) tinggi, maka agroindustri ini cocok untuk peningkatan pertumbuhan ekonomi suatu wilayah. Sebaliknya apabila agroindustri tersebut bagian tenaga kerjanya tinggi, maka tipe agroindustri ini cocok untuk pemerataan kesempatan kerja.

Penelitian yang dilakukan oleh (Wiyono, 2015), memiliki nilai tambah tahu sebesar Rp10.337,72 per kilogram. Hal ini menunjukan bahwa setiap satu kilogram kedelai setelah mengalami proses produksi mampu memberikan nilai tambah sebesar Rp10.337,72 per kilogram.

\section{Faktor-faktor yang Memengaruhi Nilai Tambah}

Analisis regresi linier adalah teknik statistika yang dapat digunakan untuk menjelaskan pengaruh variabel bebas (independent variable) terhadap variabel tak bebas (dependent variable). Salah satu asumsi yang harus dipenuhi untuk melakukan pengujian hipotesis terhadap parameter pada analisis regresi linier berganda adalah tidak terjadinya korelasi antar 
variable bebas (multikolinier) (Marcus et al., 2012).

Hasil regresi menunjukkan bahwa nilai $\mathrm{R}$ Squared sebesar 0,745 yang artinya, sebesar $74,5 \%$ variabel independen (kapasitas produksi, jumlah bahan baku, harga bahan baku, harga ouput, upah tenaga kerja, tenaga kerja dan sumbangan input lain) menjelaskan variabel dependen (nilai tambah) di Desa Kalisari, dan selebihnya sebesar $25,5 \%$ dipengaruhi oleh variabel lain yang tidak dijelaskan dalam model. Nilai $\mathrm{F}$ hitung sebesar 17,316 lebih besar dari $F$ tabel sebesar 2,310 $(\alpha=5 \%$ dan $\mathrm{df}$ $1=7$, df $2=32$ ) yang artinya $H_{a}$ diterima dan $\mathrm{H}_{0}$ ditolak maka kapasitas produksi, jumlah bahan baku, harga bahan baku, harga ouput, upah tenaga kerja, tenaga kerja dan sumbangan input lain berpengaruh secara bersama-sama terhadap nilai tambah kedelai menjadi tahu kuning.

Penjelasan hasil regresi dengan t-tabel sebesar 2,037 $(\alpha=5 \%$ dan $\mathrm{df}=32)$, sebagai berikut:

a. Nilai t hitung variabel kapasitas produksi (X1) sebesar 3,112 lebih besar dari 2,037 yang artinya $\mathrm{H}_{\mathrm{a}}$ diterima dan $\mathrm{H}_{0}$ ditolak maka bahan baku berpengaruh positif dan signifikan terhadap nilai tambah kedelai pada produksi tahu kuning. Variabel kapasitas produksi yang dimaksud merupakan hasil dari produksi tahu kuning yang dihasilkan sehingga semakin banyak jumlah kedelai yang diolah maka akan semakin banyak jumlah tahu kuning yang dihasilkan. b. Nilai t hitung variabel jumlah bahan baku (X2) sebesar 2,240 lebih besar dari 2,037 yang artinya $\mathrm{H}_{\mathrm{a}}$ diterima dan $\mathrm{H}_{0}$ ditolak tetapi biaya bahan baku berpengaruh negatif dan signifikan terhadap nilai tambah kedelai pada produksi tahu kuning. Variabel jumlah bahan baku yang dimaksud merupakan banyaknya kedelai yang digunakan untuk menghasilkan tahu kuning.

c. Nilai t hitung variabel tenaga kerja (X3) sebesar 2,914 lebih besar dari 2,037 yang artinya $\mathrm{H}_{\mathrm{a}}$ diterima dan $\mathrm{H}_{0}$ ditolak maka tenaga kerja berpengaruh negatif dan signifikan terhadap nilai tambah kedelai pada produksi tahu kuning. Variabel tenaga kerja yang dimaksud merupakan banyaknya tenaga kerja untuk memproduksi kedelai dalam satuan HOK. Berdasarkan analisis, variabel tenaga kerja yang diperoleh signifikan namun berpengaruh negatif hal ini disebabkan dalam melakukan kegiatan sudah dibantu dengan adanya penerapan teknologi. Hal ini sesuai dengan penelitian terdahulu yang dilakukan oleh Wantasen dan Paputungan (2017). Pada fungsi produksi berlaku hukum The Law of Diminishing Return, jika penggunaan satu input (tenaga kerja) ditambah sedang inputinput lain tetap maka setiap output yang dihasilkan dari setiap tambahan satu unit input (tenaga kerja) yang ditambahkan tadi mula-mula naik tetapi kemudian menurun hingga mencapai nilai negatif.

Tabel 3. Hasil estimasi faktor-faktor yang memengaruhi nilai tambah kedelai

\begin{tabular}{lrrr}
\hline \multicolumn{2}{c}{ Koefisien } & Standard Error & $\mathrm{t}$ \\
\hline Constant & $-446,396$ & 7655,092 & $-0,058$ \\
Kapasitas produksi & $40,703^{* *}$ & 13,078 & 3,112 \\
Bahan Baku & $-27,906^{* *}$ & 12,456 & $-2,240$ \\
Tenaga Keja & $-1153,04^{* *}$ & 395,712 & $-2,914$ \\
Harga Ouput & $1,809^{* *}$ & 0,173 & 10,453 \\
Upah Tenaga Kerja & $0,024^{\mathrm{ns}}$ & 0,034 & 0,704 \\
Harga Bahan Baku & $-0,711^{\mathrm{ns}}$ & 1,024 & $-0,694$ \\
Sumbangan Input Lain & $-1,316^{* *}$ & 0,553 & $-2,377$ \\
F statistic & 17,316 & & \\
R Square ( ${ }^{2}$ ) & 0,791 & & \\
\hline Keterangan: ** Signifikan pada taraf signifikan $\alpha=0,05$ & & \\
ns Tidak Signifikan & & &
\end{tabular}


d. Nilai t hitung variabel harga output (X4) sebesar 10,453 lebih besar dari 2,037 yang artinya $\mathrm{H}_{\mathrm{a}}$ diterima dan $\mathrm{H}_{0}$ ditolak maka bahan baku berpengaruh positif dan signifikan terhadap nilai tambah kedelai pada produksi tahu kuning. Variabel harga output yang dimaksud merupakan harga produk yang telah selesai diproduksi dinyatakan dalam satuan kilogram $(\mathrm{Rp} / \mathrm{kg})$.

e. Nilai t hitung variabel upah tenaga kerja (X5) sebesar 0,704 lebih kecil dari 2,037 yang artinya $\mathrm{H}_{\mathrm{a}}$ ditolak dan $\mathrm{H}_{0}$ diterima maka upah tenaga kerja tidak berpengaruh terhadap nilai tambah kedelai pada produski tahu kuning. Variabel upah tenaga kerja yang dimaksud merupakan imbalan yang diterima oleh tenaga kerja dari hasil pekerjaannya yang dinyatakan dalam rupiah per satuan kilogram. Hasil ini linier dengan Ningsih dan Indrajaya (2015).

f. Nilai $t$ hitung variabel biaya bahan baku (X6) sebesar 0,694 lebih kecil dari 2,307 yang artinya $\mathrm{H}_{a}$ ditolak dan $\mathrm{H}_{0}$ diterima, sehingga biaya bahan baku berpengaruh negatif dan tidak signifikan terhadap nilai tambah kedelai pada produksi tahu kuning. Variabel biaya bahan baku yang dimaksud merupakan jumlah uang yang mampu dikeluarkan untuk membeli bahan baku. Semakin besar biaya yang dikorbankan maka semakin banyak jumlah kedelai yang dibeli sehingga tahu kuning yang dihasilkan juga semakin banyak.

g. Nilai t hitung variabel sumbangan input lain (X7) sebesar 2,377 lebih besar dari 2,037 yang artinya $\mathrm{H}_{\mathrm{a}}$ diterima dan $\mathrm{H}_{0}$ ditolak. Sumbangan input lain berpengaruh negatif dan signifikan terhadap nilai tambah kedelai pada produksi tahu kuning. Variabel sumbangan input lain terdiri atas biaya bahan baku penolong, biaya bahan bakar, biaya kemasan, transportasi, retribusi pasar dan biaya penyusutan

Nilai kontan menunjukkan apabila variabel kapasitas produksi, jumlah bahan baku, tenaga kerja, harga output, harga bahan baku, upah tenaga kerja dan sumbangan input lain tidak mengalami perubahan atau sama dengan nol maka nilai tambah berada pada titik yang senilai dengan -446,396, apabila tidak terjadi proses pengolahan maka setiap pengrajin tersebut tetap mengeluarkan biaya seperti biaya penyusutan dan akan menurunkan nilai tambah.

Koefisien regresi variabel kapasitas produksi X1 sebesar 40,703 menunjukkan bahwa setiap kenaikan satu satuan variabel kapasitas produksi akan meningkatkan nilai tambah sebesar 40,703 satuan. Sebaliknya, kenaikan bahan baku dan tenaga kerja sebesar satu satuan akan menurunkan nilai tambah sebesar 27,906 dan 1153,04 satuan.

Koefisien regresi variabel harga output X4 sebesar 1,809 menunjukkan bahwa setiap kenaikan satu satuan variabel harga output akan memiliki meningkatan nilai tambah sebesar 1,809 satuan. Hal ini disebabkan apabila harga output yang digunakan meningkat namun variabel lainnya tetap maka akan menaikkan nilai tambah. Sedangkan koefisien regresi variabel sumbangan input lain X7 sebesar 1,316 menunjukkan bahwa setiap kenaikan satu satuan variabel sumbangan input lain, justru akan menurunkan nilai tambah sebesar 1,316 satuan.

\section{KESIMPULAN}

Nilai tambah pengolahan kedelai menjadi tahu kuning sebesar Rp11.628 atau 53,85\%. Rasio nilai tambah pengolahan kedelai menjadi tahu kuning termasuk dalam rasio tinggi. Distribusi nilai tambah untuk pendapatan tenaga kerja sebesar $13,38 \%$, sumbangan input lain sebesar $18,54 \%$ dan untuk keuntungan sebesar $68 \%$. Distribusi marjin terbesar untuk keuntungan produsen. Hal tersebut menunjukkan bahwa produksi tahu kuning dapat mencapai tingkat keuntungan yang tinggi. Faktor kapasitas produksi $(\mathrm{kg})$ dan harga output (Rp) berpengaruh positif terhadap nilai tambah produksi tahu kuning di Desa Kalisari, sedangkan jumlah bahan baku (kg), tenaga Kerja (HOK) dan sumbangan input lain berpengaruh negatif. Faktor Upah Tenaga Kerja (Rp) dan harga bahan baku (Rp) tidak berpengaruh terhadap nilai tambah produksi tahu kuning.

Sebaiknya pengrajin tahu melakukan pengembangan usaha yang dimilikinya dengan menambah varian macam tahu karena usaha industri tahu ini cukup menguntungkan dan memiliki prospek yang sangat baik. Selain itu, nilai tambah produk ini juga tergolong tinggi. Pengrajin tahu di Desa Kalisari juga perlu 
melakukan perencanaan mengenai kebutuhan jumlah bahan baku dan jumlah bahan bahan input lainnya secara tepat agar dapat meningkatkan keuntungan.

\section{DAFTAR PUSTAKA}

Abdillah, R. (2015). Proyeksi dan konsumsi kedelei Indonesia. Jurnal Ekonomi Kuantitatif Terapan, 8(1), 9-23.

Andarwulan, N. L. (2018). Pengaruh perbedaan jenis kedelei terhadap kualitas mutu tahu. Jurnal Mutu Pangan, 5(2), 66-71.

Azmita, N. V. (2019). Analisis nilai tambah dan profitabilitas usaha tahu alami di Kecamatan Koto Tengah Kota Padang. Jurnal of Socio Economic on Tropical Agriculture, 1(3), 30-39.

Gujarati. (2006). Ekonometrika Dasar. Jakarta: Erlangga.

Hasanah, U, Masyhuri, \& Djuwari. (2015). Analisis nilai tambah agroindustri sale pisang di Kabupaten Kebumen. Ilmu Pertanian, 18(3), 141-149.

Marcus, G L, H J Wattimena, A., \& Lesnussa. (2012). Analisis regresi komponen utama untuk mengatasi masalah multikolinearitas dalam analisis regresi linier berganda (studi kasus: curah hujan di Kota Ambon tahun 2020). Jurnal Barekeng, 6(1), 31-40.

Nazir, M. (2011). Metode Penelitian. Bogor: Ghalia Indonesia.
Ningsih, N, M, C., \& Indrajaya, I, G, B. (2015). Pengaruh modal dan tingkat upah terhadap nilai produksi serta penyerapan tenaga kerja pada industri kerajinan perak. E-Jurnal Ekonomi Pembangunan Universitas Udayana, 4(3), 139-219.

Priantara, D. G. (2016). Analisis nilai tambah pengolahan kopi Arabika Kintamani Bangli. Jurnal Rekayasa dan Manajemen Agroindustri, 4(4), 33-42

Setyawan, F., Darwanto, D. H., \& Waluyati, L. R. (2016). Permintaan kedelai pada industri tahu di Kabupaten Kebumen. Agro Ekonomi, 27(2), 215-232.

Sudiyono, A. (2004). Pemasaran Pertanian. Malang: Universitas Muhammadiyah Malang Press.

Sugiyono. (2017). Metode Penelitian Pendidikan Pendekatan Kuantitatif, Kualitatif dan $R \& D$. Bandung: Alfabeta Press.

Wantasen, E., \& Paputungan, U. (2017). Faktor-faktor yang memengaruhi nilai tambah usaha ternak sapi di Desa Tumaratas Kecamatan Langowan Barat. Jurnal Zootek, 37(2), 294-302.

Wiyono, T. (2015). Analisis pendapatan dan nilai tambah usaha tahu pada industri rumah tangga "Wajianto" di Desa Ogurandu, Kecamatan Bolano Lambunu Kabupaten Parigi Moutong. Agrotekbis, 3(3), 421-426. 